\title{
Reflexivity in Performative Science Shop Projects
}

\section{Raoul Beunen Martijn Duineveld Roel During}

\author{
Gerard Straver \\ Albert Aalvanger \\ Wageningen University and Research \\ Centre
}

Gateways: International Journal of Community Research and Engagement Vol 5 (2012): 135-51

(C) UTSePress and the authors

ISSN 1836-3393
Science shops are organisations within universities or other knowledge institutes that conduct scientific research on behalf of citizens and local civil society. Since the first initiatives in the 1970s, a multitude of intellectual shapes and institutional forms has evolved, in which the relationship between the knowledge institute, its clients and the aims of the projects can vary widely (de Bok \& Steinhaus 2008; Leydesdorff \& Ward, 2005). The work of the science shop is mainly funded by the knowledge institute and is considered a means to bridge the gap between scientists and the public and to improve the societal impact of the institute. The science shops provide non-government organisations (NGOs) and local communities access to scientific knowledge and the opportunity to engage with scientific research and through this are in line with calls for more open and contextualised forms of scientific research (Baum 2000; Greenwood \& Levin 2007; Lam \& Bertilsson 2003; Nowotny, Scott \& Gibbons 2001).

Many organisations that ask for help from a science shop aim to empower themselves as representatives of marginalised interests within a decision-making process. According to Aalbers and Padt (2010), there are three main reasons for organisations to commission a research project through a science shop:

-to influence a specific planning or decision-making process

- to develop new knowledge that can help to present a fresh perspective within a specific discussion

- to develop their own initiative through the retrieval of scientific knowledge and insights.

Science shop projects are in vogue with the growing interest in increasing the impact of scientific research on society, and an analysis of these projects can provide a valuable contribution to the debate about action research (Cassell \& Johnson 2006; Nowotny, Scott \& Gibbons 2001; van Paassen et al. 2011). There is a growing awareness of the changing position of science in public policy among researchers, as well as among policy-makers, politicians and consultants (Beunen \& Opdam 2011; Ellis \& Waterton 2005; Fischer 2009; McNie 2007). Several studies have shown that within decision-making practices knowledge is not 
simply used, but strategically produced, contested and ignored (Ellis \& Waterton 2005; Fischer 2009; McNie 2007). The role that knowledge can play, and the kind of knowledge that can be useful, therefore depends on the context and the questions at hand. Experts cannot escape the power plays in which knowledge is constructed, contested and used (Flyvbjerg 1998; Hernstein-Smith 2005; Hillier 2002), and this awareness raises some important questions. Can researchers, for example, meet the multitude of (sometimes conflicting) expectations from the actors involved and still ensure the scientific quality of their research? And what are the democratic consequences of researchers becoming entangled in the political domain of public policy?

Although a wide variety of researchers have studied the performance of action research and discussed its pro and cons (for example, Berardi 2002; Irwin 2001; Martin 2008; van Paasen et al. 2011) and various issues have been discussed from a more critical perspective, many reflections mainly stress the success of a project and the important role of the specific researchers in producing this success (Mosse 2005). While it is naive to assume that action-research projects are always successful, it is hard to find critical reflections (or self-reflections) that address the frustrations of researchers and other participants in these projects, of the conflicts caused by the projects or the limitations of action research. Reporting on the successful performance of action research seems to be necessary to maintain a central position within a field, to obtain new funding, and so on (cf. Rap 2006; Van Assche et al. 2011). Such studies, however, do not help to produce useful insights into the complex deliberations and power struggles that often characterise decision-making processes, where power and knowledge are inextricably entwined (cf. Fischer 2009). Nor do they help to deepen our understanding of the mechanisms that bring about changes and the particular roles scientists play within these processes.

Few studies pay attention to the way in which the role and position of the researchers influence the process and its outcomes. In this article we investigate how reflexivity can help researchers to create a better understanding of their own role and position within a project. First, we elaborate briefly on power and knowledge interactions in action research, establishing this as a framework from which we can reflect on the experiences gained from some of the Wageningen University and Research Centre (Wageningen UR) Science Shop projects. To this end, three projects are described as an illustration of some possible challenges and tensions researchers may face in science shop projects. We then elaborate on some of the dilemmas associated with the role and position of action researchers participating in science shop projects.

\section{POWER AND KNOWLEDGE IN ACTION RESEARCH}

Various authors have published on the relationship between science and society or, in more abstract terms, power-knowledge 
interactions (e.g. Duineveld \& Van Assche 2011; Fischer 2009; Flyvbjerg 2002; Latour 2004). Foucault (1994, pp. 81-102) has shown how power can be repressive as well as productive: power produces, for example, some discourses, realities, knowledge, values and subjects, and makes others impossible by marginalising or subjugating them. In line with his work, others have shown the power strategies that different actors have used to attain their objectives (Flyvbjerg 2002). One of these strategies is the selective use of certain (scientific) knowledge and the conscious concealing or marginalising of research that does not work to one's advantage. This makes the role scientific knowledge can play in planning and decision-making practices an important and recurring theme in many studies. Within decision-making processes, scientific knowledge functions as an advocate for or rejection of certain claims. Involved organisations and actors produce knowledge to reinforce their power position while de-legitimising the knowledge of competing organisations, practitioners and citizens. As a consequence, the participants in the decision-making process are regularly confronted with different studies showing contradictory results.

To gain a better understanding of the role of scientific knowledge within the decision-making process, it is necessary to have a better understanding of the mutual relationship between power and knowledge. Most science shop projects operate in situations of great power inequalities stemming from the weak position of citizen groups in the decision-making network and the fact that they often lack access to important resources such as money and knowledge. In order to understand the impact of these power inequalities on the production and use of scientific knowledge, we should acknowledge that power produces knowledge: 'There is no power relation without the correlative constitution of a field of knowledge, nor any knowledge that does not presuppose and constitute at the same time, power relations' (Foucault 1977, p. 27). Since power and knowledge are always entwined, it is impossible to step aside from relationships of power and produce 'objective', 'independent' knowledge. Foucault has shown that knowledge is defined within discourses as a set of practices or strategic games within which realities are produced that both open and close reality for us because of the necessity for selection and simplification (Foucault 1994). Each discourse, each perspective on a part of reality, creates that reality for us, but the choices implied (this or that construction) simultaneously veil alternative constructions - alternative delineations of objects and subjects, backgrounds and relations. Power and knowledge shape each other; power conflicts imply or give rise to conflicting versions of reality, and vice versa (cf. Flyvbjerg 1998). The action researcher is part of these power relationships which influence what counts as knowledge and which knowledge is subjugated or marginalised. In order to understand how knowledge is produced and used in science shop projects, we should therefore account for the role 
and position of the researcher and make them the object of study. Such reflections on the work of researchers link to the literature on reflexivity (Cooper \& Burnett 2006).

Our definition and use of reflexivity derives from several sources. There is the French post-structuralist tradition of Pierre Bourdieu (Bourdieu 2003; Bourdieu \& Wacquant 1992), Michel Foucault $(1973,1994)$ and Roland Barthes $(1957)$, as well as the sustained reflection on the role of the researcher in knowledge creation that has taken place in anthropology since the 1970s (Denzin 1997; Geertz 1973; Inglis 2000; Mauthner \& Doucet 2003). Pierre Bourdieu attempted to make the disciplines of sociology and anthropology more reflexive (Bourdieu 2003; Bourdieu \& Wacquant 1992; Reed-Danahay 2005). For Bourdieu, a reflexive sociology is a sociology that duplicates its scientific labour. It objectifies not only the social reality of others but also the researcher and his or her research. He gives the following description:

By [reflexivity] I mean the objectivation of the subject of objectivation, of the analysing subject - in short, of the researcher herself ... What needs to be objectivized, then, is not the anthropologist performing the anthropological analysis of a foreign world, but the social world that has made both the anthropologist and the conscious or un-conscious anthropology that she (or he) engages (Bourdieu 2003, p. 282).

Bourdieu, leaning on Foucault and Barthes, identified reflexivity to a large extent with the uncovering of latent assumptions, with 'the systematic uncovering of unthought, intuitive, embodied categories which themselves are preconditions of conscious practice' (Howe \& Langdon 2002). He argued that researchers must always reflect critically on the effects of their choices, actions and interests. This is particularly important in the field of action research, an activity that includes collective choices and collective investments in the future. The role of action researchers in society and the positionality of their knowledge and skills shape in a fundamental manner the organisation of space and the options left open for the future (Howe \& Langdon 2002).

All forms of reflexivity spring from the positionality of knowledge (Adams 1999; Bal 2002). Positionality can be understood as the contextual construction of knowledge: knowledge is produced in a series of contexts and the conditions of creation leave marks that cannot be erased entirely later (Van Assche 2007). Reflexivity is seen as a sustained reflection on the positionality of knowledge (cf. Sletto 2010), ranging from local and informal to general and formally codified knowledge. In this respect, reflexivity addresses the political dimension of knowledge, both in its construction and in its application (Bourdieu \& Wacquant 1992). A focus on reflexivity implies that researchers should think consciously about the possible (and 
also the unintended and unwanted) transformation of the power relationship in a specific situation and their own role within these transformations.

This theoretical perspective enables researchers to explore systematically the various roles they themselves, their organisations and their knowledge play within a specific science shop project or in related action-research projects.

\section{THREE EXAMPLES OF SCIENCE SHOP PROJECTS}

This article is based upon the experiences from science shop projects of Wageningen UR in the Netherlands, three of which are used to illustrate some of the challenges researchers may face during their projects. The Wageningen UR Science Shop supports non-profit organisations by conducting research projects in the fields of nutrition and health, sustainable agriculture, water management, environmental quality, and processes of social change. In the past 25 years, the Science Shop has conducted over 260 projects, dealing with societal effects of agriculture, food, animal welfare, traffic and spatial planning (Aalbers \& Padt 2010). After a non-profit organisation contacts the Science Shop, a researcher will be approached and asked to assess if the research is new and relevant and if there is enough societal support to conduct the research. If all questions are answered positively the researcher will write a project proposal. This proposal is then discussed with the client and a steering committee. The main objective of the steering committee is to advise the researchers about the project and to help embed the results of the project in societal and political debates. The steering committee consists of experts who have particular knowledge about the subject and social networks through which the results of the projects can be disseminated. Active participation is requested from the client during all phases of the project.

In this section we briefly describe three projects of the Wageningen UR Science Shop to show their effects on power relationships and knowledge production and the dilemmas that arose for the scientists working on these projects. The description focuses on the changing role and position of the researchers as well as the dynamics and interactions by which these were influenced. We describe only briefly the substantial aspects of the projects since our focus is on the process. The analysis draws upon our own experiences with different science shop projects and open interviews with the project leaders and other stakeholders involved in these three science shop projects. Interviews were concerned with both the development of the process and the project outcomes. Particular attention was paid to the different roles of the researchers, the difficulties that were faced during the process, the social and political dynamics that influenced the project, the conflicts between different parties, and the most important reasons why certain obstacles could be tackled along the way. We studied 
various articles in local newspapers that were published before, during and after the projects in order to understand the local context in which the projects were conducted.

\section{Noordwaard Research Project}

A group of farmers living in the Noordwaard, a polder (a lowlying area enclosed by dikes) in the south-western part of the Netherlands, was alarmed by government plans to increase the water discharge capacity of the river Rhine. These proposed removing and replacing some dikes, which would result in the Noordwaard farmland being taken out of production. The land would then be used to create space for the river when there was a threat of flooding. In response to these plans, the farmers started to lobby for alternative solutions with less impact on the agricultural sector. The group was in need of independent experts who could relate the farmers' ideas to the government plans and who could judge the necessity of giving up a large part of farming land in the area. Quite by coincidence, the farmers got in touch with the Science Shop of Wageningen UR, and asked it to review an alternative plan for increasing the discharge capacity of the river. Their request was granted and the project began (Pleijte et al. 2005).

The research project showed that the Noordwaard group was marginalised in the government's decision-making process: their knowledge and alternative ideas were not being taken into account. An inhabitant explained: 'Why are we not allowed to ask an independent researcher paid by Rijkswaterstaat? Where have three years of talking led us to? I feel sad, tired and angry. We are all very polite towards each other, but what have we gained from years of respectful interaction?'. The government plans were based on a river discharge computer simulation and the water management administration was not willing to consider the farmers' suggestions for an alternative plan. The government did not favourably view the alternative plan and simply refused to see it as an input to the hydraulic river model that had been developed to calculate the efficiency of the government plan. The group of farmers did not have access to another computer model that could be used to evaluate the implications of their ideas, so they turned to the university that had developed the hydraulic river model. This was in vain, however, because the scientists were afraid that the possible outcome could jeopardise their good relationship with the water management administration.

The scientists who became involved in the Science Shop project were not hydraulic specialists. They specialised in policy analysis and landscape ecology. Initially they tried to improve the quality and status of the alternative plan in a workshop that included specialists on river management, climate change, hydraulics, etc. These experts were asked to provide a critical analysis of the alternative put forward by the group of farmers in order to improve the feasibility of this plan. Expert workshops in which local knowledge was fused with scientific knowledge were 
organised (Pleijte et al. 2005). However, the government project organisation stuck to its initial refusal to calculate the effects of the alternative plan. A member of the parliament agreed with them: 'What has happened is almost staggering. You ask people to work on a solution that guarantees safety. There is a commitment that generous compensation should come, as people have to move. We all say that public support is very important. But by all sorts of awkward actions and uncertainties people do not feel [they have been] taken seriously' (Anon. 2008).

In response, the Noordwaard farmers chose another strategy. They began to criticise the government model and its underlying assumptions, and conveyed their criticism to politicians and lobbied for their alternative plan. The politicians became aware that the water administration officials had developed 'tunnel vision'. The project organisation responded to this criticism by urging individual members of the farmers' group to be cooperative; it also indicated that higher land sale prices would be possible if farmers cooperated in selling their properties. Moreover, resistance was said to adversely affect the interests of those people in the Noordwaard who had decided to sell their properties and stop farming. Every day an officer of the project organisation visited one farmer who was seen as the opinion leader in the group. These visits occurred unannounced during work hours. The officer's objective was to stop the farmer resisting the government's plan. The result was that the community fell apart and heavy tensions became apparent between the farmers who were cooperative and those who resisted the proposed plans.

Meanwhile, the scientists from Wageningen UR were invited to appear before the parliamentary committee for water management to clarify the situation. The politicians became alarmed by the self-referentiality of the water administration. First, they spoke to the chairman of the Committee for Water Affairs, who belonged to one of the governmental parties (Christian Democrats). He was very cautious in his reactions, even expressing his concerns about his own position. After consulting his committee, he gave an assignment to the Research and Verification Office of the Staten Generaal (parliament) to clear up the vague discussion about facts, figures and local alternatives to the government project. This seldom occurs, and only where there is lack of trust between politicians and administration. The Verification Office confirmed the tunnel vision of the administration, not only concerning the Noordwaard project but also projects in many other locations. They concluded that local knowledge and alternative plans were systematically sidelined during the planning processes. Later, the Science Shop researchers were invited to participate in an expert meeting organised by the above-mentioned committee. The discussion in the political arena troubled the Noordwaard community even further. Members of the farmers' group gave warning signals of a state of despair in those who were torn between becoming cooperative or staying on the track of resistance until the procedure as a whole had been 
completed. As one of the Science Shop project leaders explained, '... the effect of the Science Shop project on the governmental planning process was rather significant: the officials of the project organisation felt attacked. The researchers in the Science Shop project inadvertently hardened the relationship between the farmers' group and the project organisation'. To avoid further escalation of the problem, the researchers and the Science Shop coordinator decided not to publish the final report. With the approval of the farmers' group, the confidential report was handed over to the parliament in the hope that it could improve the quality of both the discussion and the decision. However, the parliament simply approved the government plans without much discussion. The Science Shop project failed to change the power inequality between the project organisation and the community and did not manage to influence the closed knowledge construction process upon which the government plan was based.

\section{'Village Identity' Research Project}

Many local communities in the Netherlands are currently developing a so-called 'Village Vision'. In this document, villagers describe their wishes for the near and long-term future of their village and address social and spatial issues and developments important to them. The development of a Village Vision is often organised by the village council, a group of citizens that can ask for help and guidance from a supporting organisation funded by provincial authorities. These supporting organisations, however, had questions relating to the role of the collective identity of the villagers within a Village Vision. They asked the Science Shop of Wageningen UR for help, and the 'Village Identity' project was initiated (Aalvanger \& Beunen 2011). The aim of this project was to develop various methods that could be used by villagers to make the identity of their village explicit, which could be used as input to a Village Vision.

Five different methods were developed, drawing upon a theoretical understanding of collective identity. The methods were tested during eight meetings in three villages. Feedback from these meetings was used to assess the extent to which the different methods were suitable for making the identity of a village explicit. During the project, the researchers faced three important dilemmas:

-the balance between theory and practice

- the position of the researcher in the discussion between citizens and local government

- the effects of the project on the construction of collective identities within a village.

With regard to the first dilemma relating to the balance between theory and practice, theoretical explorations of collective identities have shown the constructed nature and fluidity of identities. Identity is continuously changing and the construction of collective identities is largely affected by contemporary issues. Coming up with a definition of the village identity is difficult, if 
not impossible, since 'the village identity' does not exist and even more so because the development of a Village Vision, and the discussions about the village identity, affect the construction (and reconstruction) of collective identities in the village (Aalvanger 2011). However, such an abstract, theoretical reflection might not be considered helpful by the organisations that commissioned the research project, as many of them held to the idea that it was possible to give a clear, unambiguous description of village identity. In addition, the village councils would need specific input to the development of a vision and there was doubt whether they could translate, by themselves, theoretical insights into a specific context. The researchers therefore concluded that a more pragmatic approach that did justice to both theory and practice was required. One researcher explained that 'identities may overlap, but may also be conflicting. In that sense, the village council should find a way to connect the different identities'. Such an approach would allow researchers to explain to those who commissioned the project the complexity of identity construction, while also providing them with some methods that could be applied during the development of a Village Vision.

The second dilemma related to the fact that a Village Vision is an instrument that can help villagers to influence the policies and plans of a municipality. This was even promoted by a member of the parliament who argued that 'municipalities have to get used to the fact that it will be quite common to make an agreement with the villages'. The meetings were predominantly organised as an experiment to test different methods for making the collective identities explicit. However, the feedback from the meetings was also interesting to the village councils, as it gave them a general overview of what the villagers wanted. In one instance, the results of the research project were used in a discussion with the municipality to put forward the perspectives and ideas of the villagers. The villagers asked the researcher to take a stand during the discussion, knowing that a researcher from Wageningen University might be more persuasive and help them to gain a stronger position in the discussion. Although empathy was felt for the villagers' request, the researcher refused. This decision was understood and accepted by the villagers, but at the same time regretted. This indicates that the researcher needs to reflect continually on his or her own behaviour. Citizens, consciously or unconsciously, sometimes require a researcher to take a position which may entangle the researcher in a discussion from which escape may not be easy.

Finally, the research showed that the organisation of the discussions influenced the relationships amongst the villagers. During the meetings, the participants constructed a collective identity based upon a distinction between 'active villagers' and 'non-active villagers'. As one inhabitant explained, 'It is always the same people who have to pull the cart, the others never show up'. Although this did not prove to be problematic in the 
specific villages the Science Shop worked with, it is an issue of which researchers need to be conscious when using participatory methods in the construction of collective identities. The distinction between 'those involved' and 'those not involved' is made by 'those involved' and may therefore reinforce the exclusion of the noninvolved citizens and, as a consequence, may increase tensions amongst the villagers.

This project shows that the involvement of action researchers not only influences the relationship between a community and the responsible authorities, but also the relationships between people within the community. Interventions through science shop projects can bring people together, as shown by the participation at the meetings, but at the same time it may also exclude people, reinforce existing tensions within a community and even creating new ones.

\section{'Ring Road Erp' Project}

Discussion about a ring road around Erp, a little village in the municipality of Veghel (North-Brabant, the Netherlands), had divided the community for a very long time. Half of the village wanted a ring road because it would reduce traffic through the centre of the village, the other half absolutely did not want this road because it would destroy the landscape on the edge of the village and because they feared it would only attract more traffic. The ring road was seen as a way to reduce the high amount of motorised traffic on the road through the village centre and deal with associated problems. Several model studies were conducted by a specialist organisation; however, the outcomes of these studies only increased the opposition. A local pressure group, 'Erp Alert', asked the Science Shop for help, which led to the commencement of the 'Ring road Erp' project (Hoofwijk et al. 2007; Stobbelaar \& Leistra 2010).

'Erp Alert' wanted the researchers to prove that the ring road was a bad solution to the serious traffic problems in the village. The Science Shop rephrased their question into: 'What is the best solution to the traffic problem taking into account the wishes of all stakeholders in the area?' A stakeholder analysis was used to determine the criteria on which all parties agreed: safety, fast transport, no disturbance, and no decline of landscape and nature qualities. The researchers used these criteria to develop and test 11 traffic options. They concluded that the ring road was not a good solution. Furthermore, they presented a regional perspective regarding traffic flows as an approach to finding an alternative solution. This solution involved guiding traffic to the main roads, away from the village, in combination with a dead-end road to the industrial area.

The results of the Science Shop project were not well received in the village. Many people feared that this solution would delay the implementation of measures to solve the traffic problems in the village centre. For them, the ring road might not be the best solution, but it was at least a solution that could be realised 
quickly. As one inhabitant said during the presentation: 'I prefer a certain solution, the ring road, above an uncertain solution'. They were therefore very critical of the report and blamed the researchers for not presenting a 'real' solution. The researchers responded that it was not their responsibility to decide on a specific solution and that the insights they presented could be used by the municipality to do so.

About six months later, the municipality suddenly presented an alternative to the ring road. This alternative was very similar to the solution presented by the Science Shop project, which indicated that the project had helped to open up new perspectives. It had also become clear that the ring road would cost the municipality much more than the alternative solution, which for a large part would be paid for by the regional authorities. This might also have played an important role in developing an alternative solution.

This case shows that a science shop research project can help to resolve a persistent impasse. In Erp, the municipality and its traffic consultants were confronted with increasing difficulties in overcoming the growing tensions between the inhabitants to find a suitable solution. The researchers were able to come up with a solution because they included more people in their study and looked at the problem from a broader perspective. The researchers first studied the traffic situation at a regional level before coming up with a solution to the traffic problems at the local level. Furthermore, they studied the criteria on which a solution should be based, instead of focusing directly on different road options. This approach was praised and taken up by the aldermen: 'We have discussed the results of the study with a focus group. This group included representatives of all political parties. But within this group we did not have a political discussion. Everyone participated with the intent to get this issue to a successful conclusion. It has been discussed here for decades. It is now time that something should happen' (P van Erp 2008a). If researchers can maintain an independent position, the chances that their ideas will be accepted by others are stronger. At the same time, the project shows the difficulties of remaining independent. One way or another, researchers tend to be drawn into a political discussion and, as a consequence, people expect them to take sides. In this project, the researchers explicitly made clear that their role was to provide further insights into the traffic-related problems and possible solutions, but that it was the responsibility of the municipality to take a decision on this matter (Jaarsma 2007). Still, their work was heavily criticised and their solution was taken into account only after it became clear that a ring road would be too costly for the municipality.

\section{DILEMMAS ENCOUNTERED IN SCIENCE SHOP PROJECTS}

The three projects show that science shop projects often take the form of action research whereby the project and its outcomes are defined and achieved in cooperation between researchers and their clients (Aalbers \& Padt 2010). Science shop projects are a particular 
form of action research since they aim to combine scientific research with a mediation process in order to solve a societal problem. Within the projects, the researchers cooperate with local stakeholders and fulfil multiple roles as researcher, process organiser and consultant. The knowledge that is produced is used to develop further insights into the issue at hand and solutions, but the researchers also facilitate the decision-making process and act as mediator in the negotiations between the different parties. These different roles are likely to fuse, because they are fulfilled by one person or a small team of researchers working closely together. This makes it difficult to distinguish the roles and have an overview of the different expectations, tasks and responsibilities that come with these roles. Furthermore, the projects show that science shop projects are likely to become part of a political and societal debate. This debate influences the project and the work of the researchers, while at the same time the project can influence the debate and the decision-making process. The influence of the political debate was very strong in the Noordwaard project, which made it difficult to perform the research, and in the end it proved impossible to influence the decision-making process. In contrast, while the 'Ring road Erp' project was highly contested, most actors were open to expressing their ideas, discussing these ideas and taking into account the results of the scientific study.

The projects show that researchers and their projects are likely to become part of the power relations between the actors involved in the issue. In this respect the researchers can never be independent. On the one hand, the political debate and power struggles influence the role and position of the researcher and therefore the development of the research project. On the other hand, the research project can influence the political debate and the power relations between the actors involved. The latter is of course a main objective of a science shop project, but researchers need to be aware that this is not by definition a positive one.

A science shop project can help to empower groups and actors that have been marginalised or excluded from the decisionmaking process by giving a voice to them and their perspectives and knowledge, as was the case in the Noordwaard project. Civic initiatives can become so powerful that they severely affect common interests or exclude other perspectives. Researchers in a science shop project should take these consequences into account, especially if they also play an important role in steering the process. Intentionally or unintentionally, the project and its results will cause shifts in the power relationships between the different parties. In this sense, science shop projects are never neutral or objective. Researchers should also be aware that their project is likely to become part of a political struggle between different actors and should therefore reflect upon the social and democratic consequences of their project and decide in which ways and to what extent they want to become involved in local politics. On the one hand, science shop projects can help to open up new perspectives, 
empower weak organisations and give them a better position within a deliberative process of planning and decision-making. However, on the other hand, these projects also entail risks, as they may create new opposition between different groups, deepen existing conflicts or intervene in the formal democratic decisionmaking processes.

Furthermore, researchers should be aware of the influence of the sociopolitical context of their role and position. A science shop project is supposed to provide a powerful instrument for analysing problems, exploring possible solutions, and monitoring and evaluating the impact of actions taken. To do this, the researcher needs to identify with the perspectives of the person or group who has commissioned the project as methods and alternative solutions are often developed in close cooperation with this client. As a result, the researcher may end up in a compromised position because this close cooperation with one of the actors involved in an issue may make it difficult to perform an independent role within the societal debate. Other actors are likely to criticise this cooperation with one particular actor and may blame the researcher for not being independent, thereby complicating or even undermining the research and acceptance of possible outcomes. Researchers should therefore be aware of whose perspective they align with, whose power they are reinforcing and to what extent they can identify themselves with this perspective. Researchers should also understand that their position, and on account of this the roles they can play, as well as the outcomes of the project, also depend on the perspectives of other actors. This influence can be positive when actors are willing to cooperate and make use of the results of the project, but not so when some actors refuse to cooperate.

Researchers should also be aware that the fusion of research and practice might lead to a kind of 'self-referentiality' (Fuller 2009; Trigg 2004) that might restrict the scientific analysis and development of solutions. Self-referentiality refers to the framing of new information in terms of predefined concepts. This may cause blind spots, preventing the researcher from developing a fresh perspective on the issue at hand. Self-referentiality may also compromise the reliability and validity of the research process.

Science shop projects can lead to a close relationship between researcher and client, in which the researcher develops a strong empathy for the client and their problems and ambitions. This may further obscure or restrict the researcher's perspective and independence, causing the researcher to become blind to other options. Furthermore, the researcher may get too involved in the power struggles around the issue. To a certain degree, this is unavoidable. A science shop project will always have an impact on, and most likely transform, the power relationships between the various actors involved. Related to these power issues, the contested nature of knowledge (and the problem it poses for politics), policy formulation and citizen participation are also important 
to consider, as many bodies of knowledge are becoming more and more discredited. Examples can easily be found in health promotion or climate adaptation. A researcher who becomes too entangled with the interests and worldview of the group or community they are working for can put this independent position at risk. As a consequence, the research itself may become a subject of debate and controversy, consequently disempowering both the client and the researcher.

These dilemmas represent some of the challenges science shop projects may face. Therefore, in our opinion, researchers should always be critical of their own role and position within a project. This is necessary for the production of useful insights, knowledge and recommendations. Detaching from the interests of the client requires an ongoing awareness of the power-knowledge practices in which one is involved. This helps the researcher to take a different perspective on the problem or on the use of knowledge and expertise within the project and the decision-making process. Determining the appropriate contribution of science to a particular project can be made easier by a critical assessment of the utility and limitations of specific scientific tools and approaches.

\section{CONCLUSIONS}

Science shop projects favour the interaction between science and society. These projects have the potential to challenge or change ossified power structures that discriminate between truth and un-truth. Bodies of knowledge produced within official planning structures are questioned and debated, yielding possible innovations with regard to the political involvement of citizens and the inclusion of informal local knowledge. The projects can inspire innovations in decision-making, in knowledge and in self-efficacy. Therefore, these projects are a very interesting experimental zone in a democratic tradition that seeks to account for the interests of a minority and include the initiatives of citizens.

This reflection on three Science Shop projects conducted by Wageningen UR shows that empowerment is far from unproblematic. Based on theoretical and practical considerations, it seems obligatory on certain occasions for researchers to step aside from the idea of empowerment and its framework of performative theories and to take a reflexive position. Reflexivity is needed to become effective instead of simply helpful. It requires questioning the power-knowledge relationships, the nature of the democratic process and the consequences of empowerment for other vulnerable groups. Harvesting the lessons of these projects requires researchers to balance performative and reflexive science.

\section{REFERENCES}

Aalbers, C \& Padt, F 2010, 25 jaar onderzoek van de Wageningse Wetenschapswinkel: Succesbepalende factoren nu en in de toekomst, Wetenschapswinkel, Wageningen UR, Wageningen, the Netherlands. 
Aalvanger, A 2011, Villagers' self-organisation in spatial planning: The relationship between village visions, village councils and collective identities within a village, Wageningen University, Wageningen, the Netherlands.

Aalvanger, A \& Beunen, R 2011, Dorpsidentiteit: Op zoek naar eenheid in verscheidenheid: vijf methoden waarmee dorpsbewoners hun dorpsidentiteit expliciet kunnen maken, Wetenschapswinkel Rapport 275, Wageningen UR, Wageningen, the Netherlands.

Adams, L 1999, 'The Mascot Researcher', Journal of Contemporary Ethnography, vol. 28, no. 4, pp. 331-363.

Bal, M 2002, Travelling concepts in the humanities: A rough guide, University of Toronto Press, Toronto.

Barthes, R 1957, Mythologies, Éditions du Seuil, Paris.

Baum, H 2000, 'Fantasies and realities in university-community partnerships', Journal of Planning Education and Research, vol. 20, no. 2, pp. $234-46$.

Berardi, G 2002, 'Commentary on the challenge to change: Participatory research and professional realities', Society and Natural Resources, vol. 15, no. 2, pp. 847-52.

Beunen, R \& Opdam, P 2011, 'When landscape planning becomes landscape governance, what happens to the science?', Landscape and Urban Planning, vol. 100, no. 4, pp. 324-326.

de Bok, C \& Steinhaus, N 2008, 'Breaking out of the local: International dimension of science shops', Gateways, International Journal of Community Research and Engagement, vol. 1, pp. 165-78.

Bourdieu, P 2003, 'Participant objectivation', Journal of the Royal Anthropological Institute, vol. 9, no. 2, pp. 281-94.

Bourdieu, P \& Wacquant, L 1992, An invitation to reflexive sociology, University of Chicago Press, Chicago, IL.

Cassell, C \& Johnson, P 2006, 'Action research: Explaining the diversity', Human Relations, vol. 59, no. 6, pp. 783-814.

Cooper, N \& Burnett, S 2006, 'Using discursive reflexivity to enhance the qualitative research process', Qualitative Social Work, vol. 5, no. 1, pp. 111-29.

Denzin, N 1997, Interpretive ethnography: Ethnographic practices for the 21st century, Sage, Thousand Oaks, CA.

Duineveld, M \& Van Assche, K 2011, 'The power of tulips: Constructing nature and heritage in a contested langscape', Journal of Environmental Policy and Planning, vol. 13, no. 2, pp. 79-98.

Ellis, R \& Waterton, C 2005, 'Caught between the cartographic and the ethnographic imagination: The whereabouts of amateurs, professionals, and nature in knowing biodiversity', Environment and Planning D: Society and Space, vol. 23, pp. 673-93.

Fischer, F 2009, Democracy \& expertise: Reorienting policy inquiry, Oxford University Press, Oxford, UK.

Flyvbjerg, B 1998, Rationality and power: Democracy in practice, University of Chicago Press, Chicago, IL. 
Flyvbjerg, B 2002, 'Bringing power to planning research: One researcher's praxis story', Journal of Planning Education and Research, vol. 21, pp. 353-66.

Foucault, M 1973, The order of things, Random House, New York.

Foucault, M 1977, Discipline and punish, Tavistock, London.

Foucault, M 1994, Power: Essential works of Foucault 1954-1984, Volume 3, The New Press, New York.

Foucault, M 1998, The will to knowledge. The history of sexuality: 1. Penguin Books, London.

Fuller, S 2009, The sociology of intellectual life: The career of the mind in and around academia, Sage, London.

Geertz, C 1973, The interpretation of cultures: Selected essays, Basic Books, New York.

Greenwood, D \& Levin, M 2007, Introduction to action research: Social research for social change, Sage, Thousand Oaks, CA.

Hernstein-Smith, B 2005, Scandalous knowledge: Science, truth and the human, Edinburgh University Press, Edinburgh, Scotland.

Hillier, J 2002, Shadows of power: An allegory of prudence in land-use planning, Routledge, New York.

Hoofwijk, H, Stobbelaar, D, Simons, R \& Jaarsma, C 2007, Verkeer is als water ... Overlast, veiligheid, bereikbaarheid en landschapskwaliteit in de casus Erp, Brabant, Wageningen UR, Wageningen.

Howe, J \& Langdon, C 2002, 'Towards a reflexive planning theory', Planning Theory, vol. 1, no. 3, pp. 209-25.

Inglis, F 2000, Clifford Geertz: Culture, custom and ethics, Polity Press, Cambridge, UK.

Irwin, A 2001, 'Constructing the scientific citizen: Science and democracy in the biosciences', Public Understanding of Science, vol. 10, no. 1, pp. 1-18.

Jaarsma, C 2007, 'Echte oplossing voor Erp bereikbaar', Brabants Dagblad, 23 October, p. 29.

Lam, M \& Bertilsson, M 2003, 'Consuming, engaging and confronting science: The emerging dimensions of scientific citizenship', European Journal of Social Theory, vol. 6, no. 2, pp. 233-51.

Latour, B 2004, Politics of nature: How to bring the sciences into democracy, Harvard University Press, Cambridge, MA.

Leydesdorff, L \& Ward, J 2005, 'Science shops: A kaleidoscope of sciencesociety collaborations in Europe', Public Understanding of Science, vol. 14, no. 4, pp. 353-72.

Martin, G 2008, “'Ordinary people only”: Knowledge, representativeness, and the publics of public participation in healthcare', Sociology of Health \& Illness, vol. 30, no. 1, pp. 35-54.

Mauthner, N \& Doucet, A 2003, 'Reflexive accounts and accounts of reflexivity in qualitative data analysis', Sociology, vol. 37, no. 3, pp. 413-31.

McNie, E 2007, 'Reconciling the supply of scientific information with user demands: An analysis of the problem and review of the literature', Environmental Science \& Policy, vol. 10, pp. 17-38. 
Mosse, D 2005, Cultivating development: An ethnography of aid policy and practice, Pluto Press, London.

Nowotny, H, Scott, P \& Gibbons, M 2001, Re-thinking science: Knowledge and the public in an age of uncertainty, Polity Press, Cambridge, UK.

van Paasen, A, van den Berg, J, Steingröver, E, Werkman, R \& Pedroli, B (eds) 2011, Knowledge in action: The search for collaborative research for sustainable landscape development, Wageningen Academic Publishers, Wageningen, the Netherlands.

Pleijte, M, During, R, Gerritsen, A \& Stuyt, L 2005, Noordwaard: Over stromingen in denken over hoogwater en natuur: ruimte voor meer stromen om de Noordwaard, Wetenschapswinkel, Wageningen UR, Wageningen, the Netherlands.

Rap, E 2006, 'The success of a policy model: Irrigation management transfer in Mexico', Journal of Development Studies, vol. 42, no. 8, pp. 1301-24.

Reed-Danahay, D 2005, Locating Bourdieu, Indiana University Press, Bloomington.

Sletto, B 2010, 'Educating reflective practitioners: Learning to embrace the unexpected through service learning', Journal of Planning Education and Research, vol. 29, pp. 403-15.

Stobbelaar, D \& Leistra, G 2010, 'Upscaling local environmental problems to create governance solutions', in Book of abstracts for Scaling and Governance Conference 2010, Wageningen, the Netherlands 11-12 November 2010, Wageningen University, Wageningen, pp. 34-35.

Trigg, R 2004, Understanding Social Science, Blackwell Publishing, Oxford, UK.

Van Assche, K 2007, 'Planning as/and/in context: Towards a new analysis of interactive planning', METU JFA, vol. 24, no. 2, pp. 105-117.

Van Assche, K, Beunen, R \& Duineveld, M 2011, 'Performing success and failure in governance: Dutch planning experiences', Public Administration, article first published online 24 October.

\section{Interviews:}

Anon 2008, 'Bijna onthutsend wat gebeurt in Noordwaard', Brabants Dagblad, 21 February, 2008.

van Erp, P 2008a, 'Oplossing beste voor heel Veghel', Brabants Dagblad, 30 October, 2008.

van Erp, P 2008b, 'Raad Veghel heeft in feite niet veel meer te kiezen', Brabants Dagblad, 31 October, 2008.

Joode, D 2005, 'ZLTO: 'Geen sprake van chantage of zware verwijten", Brabants Dagblad, 18 June, 2005. 